\title{
Aggressive gastric cancer in a patient with an APC mutation and a monoallelic MYH mutation
}

\author{
Paul Wise, Duveen Sturgeon", Reid Ness \\ From 13th Annual Meeting of the Collaborative Group of the Americas on Inherited Colorectal Cancer \\ Honolulu, Hawaii, USA. 16-17 October 2009
}

Familial Adenomatous Polyposis Syndrome (FAP) is an autosomal dominant inherited hereditary colorectal cancer syndrome that is characterized by hundreds to thousands of adenomatous colonic polyps and, without treatment and close surveillance, confers a high lifetime risk of colon cancer. Polyps usually develop in adolescence and virtually all will develop polyps by age 30 . It is caused by a mutation in the Adenomatous Polyposis coli (APC) gene which is responsible for tumor suppression and controls apoptosis. While benign fundic gland polyps are common, gastric cancer is rare in the Western population. MYH Associated Polyposis Syndrome (MAP) is an autosomal recessive disease caused by biallelic mutations in the MYH gene which is part of the base excision repair system. Patients with MAP exhibit an attenuated form of polyposis with 10's to 100 's of adenomatous polyps and have a later age of onset, typically 10 years later than FAP. Currently to be diagnosed with MAP patients must carry biallelic mutations though recent studies have described similar colon cancer risks for monoallelic carriers.

We report on a case of a 65 year old woman with an APC mutation positive FAP (de novo) who also carries a monoallelic mutation in the MYH gene G382D that developed metastatic gastric cancer within a year of a clear CT scan. She had undergone a colectomy with IRA in her 20's and had been followed by yearly endoscopic surveillance that demonstrated polyps in the remaining rectum as well as adenomatous duodenal polyps and gastric polyps with no evidence of malignancy. At 61 she was converted to a I-Pouch and continued with appropriate surveillance. At age 64 Spieglman Stage III duodenal adenomatosis was detected and EGDs were done every 3 months. In March 2008 she presented to the ER with epigastric

* Correspondence: duveen.sturgeon@vanderbilt.edu

Vanderbilt University Medical Center Nashville, Tennessee, USA pain, hematochezia and hemetemesis following an EGD and polypectomy earlier that day. A CT of the chest, abdomen and pelvis did not reveal any abnormalities. She continued to be monitored every 3 months and in March 2009 she had progressed to Spieglman Stage IV. Biopsies were obtained from the duodenal adenomas and were negative for high grade dysplasia. Two months later a CT scan revealed abnormal nodules in the liver. A diagnosis of metastatic gastric cancer was made following further studies.

Published: 25 May 2010

doi:10.1186/1897-4287-8-S1-P22

Cite this article as: Wise et al: Aggressive gastric cancer in a patient with an APC mutation and a monoallelic MYH mutation. Hereditary Cancer in Clinical Practice 2010 8(Suppl 1):P22.
Submit your next manuscript to BioMed Central and take full advantage of:

- Convenient online submission

- Thorough peer review

- No space constraints or color figure charges

- Immediate publication on acceptance

- Inclusion in PubMed, CAS, Scopus and Google Scholar

- Research which is freely available for redistribution

Submit your manuscript at www.biomedcentral.com/submit
C Biomed Central 